\title{
RESPONSE OF BARLEY GROWN IN SALT- AFFECTED SOIL TO BIO AND MINERAL FERTILIZERS
}

\author{
El-Sayed, Mahmoud A.M. and Rabaa Yaseen* \\ Department of Soil Fertility and Microbiology, Water Resources and \\ Desert Soils Division, Desert Research Center, El-Matareya, Cairo, \\ Egypt. \\ *E-mail: rabaa.yassen@yahoo.com,mahalyeg@yahoo.com
}

\begin{abstract}
A
wo field experiments were done to assess the effect of seed inoculation with single or dual plant growth promoting rhizobacterial (PGPR) strains (Azotobacter chrococcum and Bacillus subtilis) and three levels of NPK fertilization (50, 75 and $100 \%$ ) on growth and productivity of barley (Hordeum vulgare) plants growing under saline condition at El-Monira village, El-Kharga Oasis, New Valley, during the two successive seasons 2016 and 2017. Spilt plot design in four replications was used, where NPK fertilization treatments occupied the main plots and biofertilization in the sub-plot. Analysis of variance revealed significant effect of biofertilizer application along with NPK fertilizer levels on all measured growth parameters (plant height, branching, spikes number, fresh and dry weight), soil biological activity (total microbial count, dehydrogenase activity and antioxidant capacity of soil), available nitrogen and phosphorus in soil, uptake of nitrogen and phosphorus, protein content of parley plants and yield and its related characters (spikes $/ \mathrm{m}^{2}$ numbers, 1000 -grains weight and grain yield). Maximum traits were obtained by plants that were treated with $75 \%$ of NPK fertilizer and mixed cultures of A. chrococcum and B. subtilis. Thus, it could be concluded that the use of $75 \%$ chemical fertilizer along with co-inoculation with $A$. chrococcum and B. subtilis could promote the growth, productivity and disease resistance in barley under saline condition.
\end{abstract}

Keywords: Barley (Hordeum vulgare), salinity, microbial activity, biofertilizers, NPK fertilizers, soil antioxidant, New Valley

Barley (Hordeum vulgare L.) is an important and nutritious crop that could be used as fodder and cover crop to enhance soil fertility. It is rich in essential nutrients such as protein, carbohydrates, fat and fibers (Ghanbari et

The $1^{\text {st }}$ Conference of Plant Protection Science Applications for Sustainable Development of Desert Areas "Effect of Climate Change on Plant Pests and Biodiversity in Desert Environment" 19-20 October, 2019, Cairo-Egypt. 
al., 2012). Barley is a moderate salt tolerance crop and has a potency to grow in a wide range of environmental stresses including drought, heating or saline conditions (Ayman, 2015).

Salt stress can directly or indirectly affect the physiological status of plant by altering its metabolism, growth, and development and hence lead to severe crop loss every year. In Egypt, plants are exposed to extreme climatic factors; such as drought and high temperatures. Under these conditions, dissolved salts may accumulate in soils because of the insufficient leaching of ions and unsuitable irrigation management (Eisa et al., 2012).

High salinity constitutes an environmental stress also for rhizospheric bacteria. Microbial activities and population were negatively affected by salinity as revealed by Yaseen and Yossif (2019). It inhibits various physiological processes, ranging from energy and nutrient uptake to inhibition of DNA replication and macromolecule biosynthesis (Bartels and Sunkar, 2005). In addition, causes an alteration of proteins involved in the initial attachment steps of bacteria to plant roots as well as inhibition of bacterial nodulation and nitrogen fixation activity, and also inhibit the bacterial mobility and chemotaxis toward plant roots (Jofre' et al., 1998).

The excessive use of chemical fertilizers adversely affects the soil quality as well as human health. Thus, there is a need to use ecofriendly alternative like plant growth promoting rhizobacteria (PGPR) to enhance the crop yield. The PGPR are a group of bacteria that colonize plant roots, causing an increase in plant growth and yield. They are being widely used as a substitute to chemical pesticides and mineral fertilizers due to their ecofriendly nature (Reddy et al., 2014). They promote plant growth through their ability to fix $\mathrm{N}_{2}$, dissolve mineral phosphates and other nutrients, support nutrition uptake, produce siderophore, hydrogen cyanide and growth promoting hormones (auxins, gibberellins and cytokinins), and antagonize phytopathogenic microorganisms or enhance plant resistance to pathogens (Bhattacharyya and Jha, 2012). Reducing the use of chemicals in agricultural areas has great interest in order to protect plant health and reduce production costs as well as environmental pollution. For this reason, many authors tried to use bio-fertilizers in a combination with less doses of chemical fertilizers (Kurokura et al., 2017 and Parlakova Karagöz and Dursun, 2019). Zafar-ulHye et al. (2015) found that the aminocyclopropane carboxylate deaminase containing bacteria alone and in combination with mineral fertilizers improved the root and shoot growth of maize seedlings in saline-sodic soil. Incorporation of PGPR with half dose of recommended chemical fertilizers enhanced the yield of sunflower plant by reducing the use and harmful effects of chemical fertilizer on soil health and environment (Tahir and Shehzadi, 2017).

The present study was done to investigate the effect of biofertilization treatments and different levels of mineral fertilization on growth and productivity of barley under saline condition.

Egyptian J. Desert Res., 69, Special Issue, 59-75 (2019) 


\section{MATERIALS AND METHODS}

\section{Cultivar}

Barley seeds cultivar Giza 123 (Hardeum vulgare) were obtained from Field Crops Research Institute, Agricultural Research Center, Giza, Egypt.

\section{Microorganisms}

The bacterial isolates used in this experiment were isolated from salt affected soils and identified as be Azotobacter chrococcum and Bacillus subtilis according to Bergey's Manual of Systematic Bacteriology (Bergey et al., 1984).

\section{Plant Growth Promoting Properties of Bacterial Isolates}

The abilities of bacterial isolates to fix nitrogen and dissolve phosphorus were determined by growing the isolates on Ashby's and Pikovaskaya's media according to Subba Rao (1984) and Pikovskaya (1948), respectively. Production of indole-3-acetic acid (IAA) was assayed by colorimetric method (Patten and Glick, 2002). Production of exopolysaccharid (EPS) was tested using the method described by Emtiazi et al. (2004). Siderophore production was determined by the method of Rachid and Bensoltane (2005). Organic acid formation was determined using methyl red method described by Olutiola et al. (2000). Production of ammonia were determined according to Cappuccino and Sherman (1992).

\section{Agricultural Experiment}

Two field experiments were conducted in new reclaimed salt affected sandy soil at El-Monira village, El-Kharga Oasis (30.53 longitude, 25.45 latitude and elevation78.8 m), New Valley Governorate, during the two cropping seasons of 2016 and 2017 to study the response of barley plant to mineral fertilizer levels $(120,180$, and $240 \mathrm{~kg} / \mathrm{ha})$ and inoculation by $A$. chrococcum, B. subtilis, and their mixtures, and without inoculation as control. The fertilizer used was NPK 19-19-19, bacterial concentration was adjusted to $10^{8}(\mathrm{CFU} / \mathrm{ml})$ and was added at a rate of $20 \mathrm{~L} / \mathrm{fed}$. Barley seeds were treated before planting with bacterial suspensions for three hours before planting (carboxy methyl cellulose $0.5 \%$ was used as an adhesive agent).

\section{Physical and Chemical Analysis of Precultivated Soil and Irrigated Water}

The physical and chemical analysis of experimental field soil was determined according to Page et al. (1982) and presented in table (1). The chemical analyses of irrigation water were $\mathrm{pH} 7.5$ and EC $1.46 \mathrm{dS} . \mathrm{m}^{-1}$. 
Table (1). Analysis of experimental soil and irrigation water.

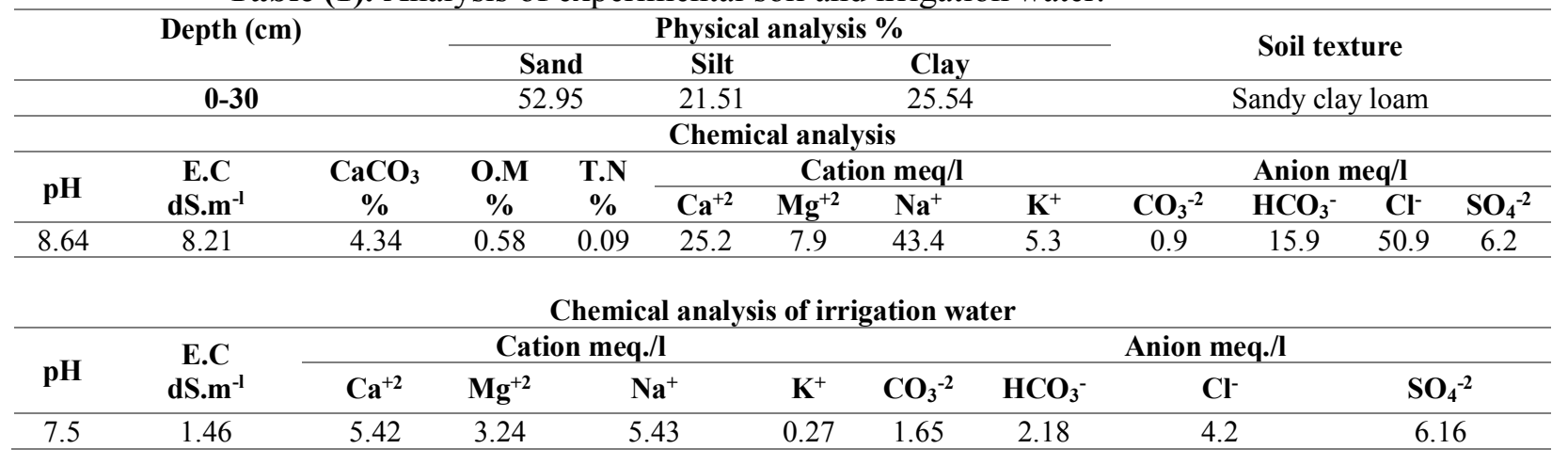

\section{Agronomic Data Recoded}

\subsection{Soil biological activity}

Total microbial counts were estimated according to Allen (1959). Microbial activity was estimated by measuring the activity of dehydrogenase (DHA) of the rhizosphere soil (Casida et al., 1964), antioxidant activity of rhizosphere soil was evaluated following the extraction procedure of Rimmer and Abbott (2011). In brief, $2 \mathrm{~g}$ soil were extracted with $5 \mathrm{ml}$ of $1 \mathrm{M} \mathrm{NaOH}$ for $16 \mathrm{~h}$ on a rotary shaker at room temperature, followed by centrifugation. The supernatants were heated at $90^{\circ} \mathrm{C}$ for $2 \mathrm{~h}$ then cooled, titrated with $4 \mathrm{M}$ $\mathrm{HCl}$ to $\mathrm{pH} 2.0$ and placed in disposable glass test tubes. The reducing power of soil extract was determined according to Bhalodia (2013).

\subsection{Chemical composition}

Seeds nitrogen content was determined by the modified microkjeldahl method as described by Peach and Tracy (1956). The protein content was calculated by multiplying the total nitrogen by 4.64 (Magomya et al., 2014). Phosphorus percentage was estimated by ascorbic acid according to method reported by Bender and Wood (2000).

\subsection{Yield and yield components}

At harvest, plant height $(\mathrm{cm})$, number of branches, fresh weight $(\mathrm{g})$, dry weight $(\mathrm{g})$, number of spikes $/ \mathrm{m}^{2}, 1000$-grain weight $(\mathrm{g})$ and grain yield $(\mathrm{kg} / \mathrm{fad}$.) were measured.

\section{Statistical Analysis}

The data were analyzed using SPSS 21.1 software program (SPSS, 2014). The ANOVA test was used to determine the significant difference between treatments (LSD). After analysis the variance means were compared with each other according to Duncan's multiple range test at $p \leq 0.05$. 


\section{RESULTS AND DISSCOUSION}

\section{Plant Growth Promoting Activities of Bacterial Isolates}

Plant growth-promotion characteristics of two biofertilizer strains were evaluated and presented in table (2). Results revealed that the two strains had the capacity to solubilize phosphate and produce IAA, exopolysaccharide, organic acids and siderophores in iron-free medium. Microorganisms with PGP activities are useful in agricultural fields and can alleviate many biotic and abiotic stresses (Wang et al., 2016). Several studies reported that stress tolerance is improved in plants by PGP microbes through different mechanisms; such as producing growth regulators and antioxidant that can detoxify reactive oxygen species resulting in increased growth parameters and most importantly enhanced nutrient content, thus improving the health of plant under salt stress (Shahid et al., 2018 and Abbas et al., 2019).

Table (2). Plant growth promoting activities of bacterial isolates.

\begin{tabular}{ccc}
\hline \multirow{2}{*}{ Characteristics } & \multicolumn{2}{c}{ Bacterial isolates } \\
\cline { 2 - 3 } & A. chrococcum & B. subtilis \\
\hline Nitrogen fixation & + & - \\
Phosphate dissolving & $+(46 \mathrm{ug} / \mathrm{ml})$ & $+(55 \mathrm{ug} / \mathrm{ml})$ \\
IAA production & $+(7.2 \mathrm{ug} / \mathrm{ml})$ & $+(4.7 \mathrm{ug} / \mathrm{ml})$ \\
Siderophore production & $+(25 \mathrm{ug} / \mathrm{ml})$ & $+(42 \mathrm{ug} / \mathrm{ml})$ \\
Exopolysaccharide & $+(8.7 \mathrm{mg} / \mathrm{ml})$ & $+(6.9 \mathrm{mg} / \mathrm{ml})$ \\
Organic acid production & + & + \\
Ammonia production & - & + \\
\hline
\end{tabular}

\section{Effect of Mineral Fertilizer Levels and Biofertilizers on Growth Parameters of Barley Plant During 2016 and 2017 Seasons Under Salt Conditions}

The analysis of variance showed a significant difference for Interaction effect between bio-fertilizer and chemical fertilizer levels in terms of plant height, branches numbers, spikes numbers, fresh and dry weight (Table 3). Application of biofertilizers (mixed culture) in growing season 2016 increased about 29.7, 39.65 and $37.7 \%$ in plant height, 48.1, 73.9 and $63.3 \%$ in branches numbers, $42.7,82.4$ and $81.3 \%$ in spikes numbers, 29.3 , 82.8 and $71.6 \%$ in fresh weight and $43.4,64.7$ and $45.2 \%$ in dry weight in comparison with control (without bio fertilizer) at 50, 75 and $100 \%$ of chemical fertilizers, respectively. While in growing season 2017 there was an increase in plant height by $54.1,35$ and $28.4 \%$, in branches numbers by 57.1 , 68.9 and $48.8 \%$, in spikes numbers by $94.6,73.6$ and $54.1 \%$, in fresh weight by $25.6,75.2$ and $62 \%$ and in dry weight by $49.7,72.5$ and $56.2 \%$ over the 
control at 50,75 and $100 \%$ of chemical fertilizers, respectively. Interaction effect between mixed culture and $75 \%$ of chemical fertilizers gave the highest growth parameters of barely plant growing under saline condition, when compared with the other two levels. Salinity is a major abiotic stress that influencing all crops in Egypt. Although barley is considered a salt tolerant crop species, productivity of barley is affected by osmotic and oxidative stresses. Babu et al. (2007) illustrated that salt stress led to decline in the rate of germination percentage and all growth parameters of barley genotypes. PGP bacteria enhanced plant growth under saline condition through producing growth promoting nutrients and growth regulators (Etesami and Maheshwari, 2018).

Table (3). Effect of mineral fertilizer levels and biofertilizers on growth parameters of barley plant during 2016 and 2017 seasons under salt conditions.

\begin{tabular}{|c|c|c|c|c|c|c|c|c|c|c|c|}
\hline \multirow[b]{2}{*}{$\begin{array}{l}\text { NPK } \\
\text { levels }\end{array}$} & \multirow[b]{2}{*}{ Inoculation } & \multicolumn{5}{|c|}{2016} & \multicolumn{5}{|c|}{2017} \\
\hline & & $\begin{array}{c}\text { Plant } \\
\text { height }\end{array}$ & BN/p & $\mathbf{S N} / \mathbf{p}$ & $\begin{array}{c}\text { Fresh } \\
\text { wt. }\end{array}$ & $\begin{array}{l}\text { Dry } \\
\text { wt. }\end{array}$ & $\begin{array}{c}\text { Plant } \\
\text { height }\end{array}$ & BN/p & $\mathbf{S N} / \mathbf{p}$ & $\begin{array}{c}\text { Fresh } \\
\text { wt. }\end{array}$ & $\begin{array}{l}\text { Dry } \\
\text { wt. }\end{array}$ \\
\hline \multirow{4}{*}{$\begin{array}{c}50 \% \\
(120 \\
\mathrm{kg} / \mathrm{ha})\end{array}$} & Control & $63.0^{\mathrm{g}}$ & $13.3^{\mathrm{g}}$ & $11.0^{\mathrm{g}}$ & $70.3^{j}$ & $47^{\mathrm{h}}$ & $67.7^{\mathrm{h}}$ & $17.0^{\mathrm{i}}$ & $13.0^{\mathrm{j}}$ & $74.9^{1}$ & $54.5^{\mathrm{k}}$ \\
\hline & PDB & $73.7^{\mathrm{f}}$ & $15.0 \mathrm{f}^{\mathrm{g}}$ & $13.7^{\text {ef }}$ & $82.8^{\mathrm{h}}$ & $51.7^{\mathrm{gh}}$ & $84.0^{\mathrm{g}}$ & $20.7^{\mathrm{h}}$ & $17.0^{\mathrm{i}}$ & $87.7^{\mathrm{i}}$ & $65.6^{\mathrm{i}}$ \\
\hline & Azot & $79.3^{\text {ef }}$ & $18.0^{\mathrm{e}}$ & $14.7^{\mathrm{e}}$ & $88.8^{\mathrm{g}}$ & $53.2^{\mathrm{gh}}$ & $98.3^{c}$ & $23.3^{\mathrm{f}}$ & $21.7^{\mathrm{fg}}$ & $90.7^{\mathrm{h}}$ & $78^{f}$ \\
\hline & Mixed & $81.7^{\text {de }}$ & $19.7^{\mathrm{de}}$ & $15.7^{\mathrm{de}}$ & $90.9^{\mathrm{g}}$ & $67.4^{\mathrm{de}}$ & $104.3^{\mathrm{b}}$ & $26.7^{\mathrm{d}}$ & $25.3^{\mathrm{d}}$ & $94.1^{\mathrm{g}}$ & $81.6^{\mathrm{e}}$ \\
\hline \multirow{4}{*}{$\begin{array}{c}75 \% \\
(180 \\
\mathrm{kg} / \mathrm{ha})\end{array}$} & Control & $74.7^{\mathrm{f}}$ & $15.7^{\mathrm{f}}$ & $13.7^{\mathrm{ef}}$ & $77.5^{\mathrm{i}}$ & $56.4^{\mathrm{fg}}$ & $85.7^{\mathrm{g}}$ & $20.3^{\mathrm{h}}$ & $19.0^{\mathrm{h}}$ & $83.6^{\mathrm{k}}$ & $62.2^{\mathrm{j}}$ \\
\hline & PDB & $91.3^{\mathrm{bc}}$ & $20.7^{\mathrm{d}}$ & $17.0^{\mathrm{cd}}$ & $104.5^{\mathrm{e}}$ & $71.7^{\mathrm{cd}}$ & $97.3^{\mathrm{cd}}$ & $25.0^{\mathrm{e}}$ & $23.7^{\mathrm{e}}$ & $112.6^{\mathrm{e}}$ & $75.7^{\mathrm{g}}$ \\
\hline & Azot & $96.7^{\mathrm{b}}$ & $23.3^{\mathrm{bc}}$ & $18.3^{\mathrm{c}}$ & $116.4^{\mathrm{c}}$ & $77.4^{\mathrm{bc}}$ & $105.0^{\mathrm{b}}$ & $29.7^{\mathrm{c}}$ & $28.7^{\mathrm{c}}$ & $121.4^{\mathrm{c}}$ & $90.9^{c}$ \\
\hline & Mixed & $104.3^{\mathrm{a}}$ & $27.3^{\mathrm{a}}$ & $25.0^{\mathrm{a}}$ & $141.7^{\mathrm{a}}$ & $92.9^{\mathrm{a}}$ & $115.7^{\mathrm{a}}$ & $34.3^{\mathrm{a}}$ & $33.0^{\mathrm{a}}$ & $146.5^{\mathrm{a}}$ & $107.3^{\mathrm{a}}$ \\
\hline \multirow{4}{*}{$\begin{array}{c}100 \% \\
(240 \\
\mathrm{kg} / \mathrm{ha})\end{array}$} & Control & $75.3^{\text {ef }}$ & $15.3^{\mathrm{fg}}$ & $12.3^{\mathrm{fg}}$ & $79.2^{\mathrm{hi}}$ & $58.3^{\text {fg }}$ & $89.0^{\mathrm{f}}$ & $21.7^{\mathrm{g}}$ & $20.3^{\text {gh }}$ & $86.3^{j}$ & $63.3^{\mathrm{j}}$ \\
\hline & PDB & $87.7^{\mathrm{cd}}$ & $19.3^{\text {de }}$ & $17.0^{\text {cd }}$ & $96.0^{\mathrm{f}}$ & $63.5^{\mathrm{ef}}$ & $93.3^{\mathrm{e}}$ & $23.3^{\mathrm{f}}$ & $22.7^{\mathrm{ef}}$ & $106.9^{f}$ & $72.7^{\mathrm{h}}$ \\
\hline & Azot & $92.3^{\mathrm{bc}}$ & $21.3^{\mathrm{cd}}$ & $18.0^{\mathrm{c}}$ & $112.2^{\mathrm{d}}$ & $71.0^{\text {cde }}$ & $95^{\mathrm{de}}$ & $26.7^{\mathrm{d}}$ & $26.0^{\mathrm{d}}$ & $115.9^{\mathrm{d}}$ & $87.7^{\mathrm{d}}$ \\
\hline & Mixed & $103.7^{\mathrm{a}}$ & $25.0^{\mathrm{b}}$ & $22.3^{\mathrm{b}}$ & $135.9^{\mathrm{b}}$ & $84.7^{\mathrm{b}}$ & $114.3^{\mathrm{a}}$ & $32.3^{\mathrm{b}}$ & $31.3^{\mathrm{b}}$ & $139.8^{b}$ & $98.9^{\mathrm{b}}$ \\
\hline \multicolumn{2}{|c|}{ LSD at 0.05} & 6.6 & 2.13 & 2.07 & 3.9 & 8.0 & 2.56 & 0.96 & 1.5 & 1.3 & 1.33 \\
\hline
\end{tabular}

$\mathrm{BN} / \mathrm{p}$ : Branches number / plant.

$\mathrm{SN} / \mathrm{p}$ : Spikes number / plant

\section{Effect of Mineral Fertilizer Levels and Biofertilizers on Soil Biological Activities in the Rhizosphere of Barley Plant during 2016 and 2017 seasons Under Salt Conditions}

Microbial density as affected by application of different NPK levels and applied biofertilizers shown in table (4). Results indicated that total microbial counts were higher with application of $180 \mathrm{~kg} / \mathrm{ha}$ than that obtained with 120 $\mathrm{kg} / \mathrm{ha}$ or $240 \mathrm{~kg} / \mathrm{ha}$. The high dose of fertilizers used in cultivated systems may restrict the microbial growth and activities in soil (Nguyen et al., 2018).

Egyptian J. Desert Res., 69, Special Issue, 59-75 (2019) 
Concerning the effect of biofertilizers, data showed an increase in microbial densities with biofertilizer application. It could be noticed that, dual inoculation significantly gave the highest results than single ones. Many studies showed that salinity reduces microbial activity, microbial biomass and changes microbial community structure (Singh, 2016; Wang et al., 2016 and Chen et al., 2017). Application of halotolerant bacteria with PGP properties enhanced the soil microbial biomass through production of osmolyte (Yasin et al., 2018).

Table (4). Effect of mineral fertilizer levels and biofertilizers on soil biological activities in the rhizosphere of barley plant during 2016 and 2017 seasons under salt conditions.

\begin{tabular}{|c|c|c|c|c|c|c|c|}
\hline \multirow{2}{*}{ NPK levels } & \multirow{2}{*}{ Inoculation } & \multicolumn{3}{|c|}{2016} & \multicolumn{3}{|c|}{2017} \\
\hline & & ТМC & AOA & DHNAS & TMC & AOA & DHNAS \\
\hline \multirow{4}{*}{$\begin{array}{c}50 \% \\
(120 \mathrm{~kg} / \mathrm{ha})\end{array}$} & Control & $35^{f}$ & $1.0^{\mathrm{i}}$ & $1.0^{\mathrm{h}}$ & $38^{1}$ & $1.3^{\mathrm{i}}$ & $1.1^{\mathrm{j}}$ \\
\hline & PDB & $50^{\mathrm{ef}}$ & $1.7^{\mathrm{g}}$ & $1.5^{\mathrm{f}}$ & $66^{\mathrm{i}}$ & $2.2^{\mathrm{g}}$ & $1.5^{\mathrm{h}}$ \\
\hline & Azot & $68 \mathrm{~d}^{\mathrm{ef}}$ & $2.0^{\mathrm{f}}$ & $1.6^{\mathrm{e}}$ & $80^{\mathrm{h}}$ & $2.3^{\mathrm{f}}$ & $1.8^{\mathrm{g}}$ \\
\hline & Mixed & $72 c^{d e}$ & $2 . .0^{1 \mathrm{f}}$ & $1.8^{\mathrm{d}}$ & $100^{\mathrm{g}}$ & $2.4^{\mathrm{f}}$ & $2.1^{\mathrm{f}}$ \\
\hline \multirow{4}{*}{$\begin{array}{c}75 \% \\
(180 \mathrm{~kg} / \mathrm{ha})\end{array}$} & Control & $40^{\mathrm{ef}}$ & $1.3^{\mathrm{h}}$ & $1.2^{\mathrm{g}}$ & $46^{\mathrm{j}}$ & $1.7^{\mathrm{h}}$ & $1.4^{\mathrm{h}}$ \\
\hline & PDB & $110^{\mathrm{b}}$ & $2.4^{\mathrm{e}}$ & $1.9^{\mathrm{c}}$ & $134^{\mathrm{e}}$ & $2.9^{\mathrm{e}}$ & $3.1^{\mathrm{d}}$ \\
\hline & Azot & $170^{\mathrm{a}}$ & $3.9^{b}$ & $2.1^{b}$ & $194^{\mathrm{b}}$ & $4.3^{\mathrm{b}}$ & $3.5^{\mathrm{b}}$ \\
\hline & Mixed & $174^{\mathrm{a}}$ & $4.1^{\mathrm{a}}$ & $2.4^{\mathrm{a}}$ & $210^{\mathrm{a}}$ & $4.5^{\mathrm{a}}$ & $3.7^{\mathrm{a}}$ \\
\hline \multirow{4}{*}{$\begin{array}{c}100 \% \\
(240 \mathrm{~kg} / \mathrm{ha})\end{array}$} & Control & $40^{\mathrm{ef}}$ & $1.5^{\mathrm{h}}$ & $1.2^{\mathrm{g}}$ & $40^{\mathrm{k}}$ & $2.0^{\mathrm{h}}$ & $1.2^{\mathrm{i}}$ \\
\hline & PDB & $106^{\mathrm{bc}}$ & $2.4^{\mathrm{e}}$ & $1.8^{\mathrm{d}}$ & $114^{\mathrm{f}}$ & $2.5^{\mathrm{e}}$ & $2.9^{\mathrm{e}}$ \\
\hline & Azot & $122^{\mathrm{b}}$ & $3.1^{\mathrm{d}}$ & $1.9^{\mathrm{c}}$ & $176^{\mathrm{d}}$ & $4.2^{\mathrm{d}}$ & $3.1^{\mathrm{d}}$ \\
\hline & Mixed & $140 b^{c d}$ & $3.4^{\mathrm{c}}$ & $2.1^{b}$ & $192^{c}$ & $4.5^{\mathrm{c}}$ & $3.3^{\mathrm{c}}$ \\
\hline LSD a & t 0.05 & 34 & 0.179 & 0.022 & 1.13 & 0.178 & 0.095 \\
\hline
\end{tabular}

TMC: Total microbial count $\times 10^{5} \mathrm{cfu} / \mathrm{g}$ dry soil

AOA: antioxidant activity of soil ug ascorbic acid /g dry soil

DHNAS: dehydrogenase umol TF /g dry soil

The impact of interaction between NPK levels and biofertilizers application on dehydrogenase activity was studied (Table 4), results showed that the highest dehydrogenase activity were obtained with application mixture of the two biofertilizers combined with $180 \mathrm{~kg} / \mathrm{ha}$. The trend of the above results was true in both investigated seasons. These results agreed with those obtained by Marwa et al. (2018). 
The antioxidant system can be considered useful indicators of the soil biological status and soil quality (Cardelli et al., 2014). Data showed that the interaction between mixed culture of bio-fertilizer and $75 \%$ of chemical fertilizer level have the greatest effect on increasing the antioxidant activity of soil in both investigated seasons. The increase in antioxidant activity in soil led to plant protection against oxidative stress resulting from high salinity (Rimmer, 2006). Skwaryło-Bednarz and Krzepiłko (2007) confirmed a close relationship between soil total antioxidant capacity in the soil and the microbial count in various soil types. Enzymatic and non-enzymatic antioxidant play an important role in plant growth and development, particularly in defense mechanisms. Prolonged exposure to environmental stress resulted in oxidative stress, causing pathological condition. Many authors suggested that peroxidases and phenolic compounds were involved in plant protection against oxidative stress (Kulbat, 2016).

\section{Effect of Mineral Fertilizer Levels and Biofertilizers on Available Minerals in the Rhizosphere of Barley Plant During 2016-2017 Seasons under Salt Conditions}

Salinity affects soil microbial communities and inhibits the mineralization of organic materials in soil, causing severe changes in the process of organic matter turnover (Chowdhury et al., 2011) and thus reduce the released of plant nutrients. Application of mixed biofertilizer cultures combined with mineral fertilizer levels significantly enhanced the availability of nitrogen and phosphorus in investigated soil (Table 5). Application of mixed biofertilizer cultures in growing season 2016/2017 increased about 96.4, 65.4 and $50.4 \%$ in available nitrogen and 59.6, 42.6 and $38.1 \%$ in available phosphorus over the control at 50,75 and $100 \%$ of chemical fertilizers, respectively. While the application of mixed biofertilizer cultures in growing season 2017/2018 increased about $75.2,87.2$ and $75.6 \%$ in available nitrogen and $49.1,74.3$ and $58.1 \%$ in available phosphorus over the control at 50,75 and $100 \%$ of chemical fertilizers, respectively. Similar results were obtained by Yaseen et al. (2018), who found that the most significant factor affected NPK availability in soil was biosurfactant producing bacteria. PGPR play an essential role in nutrient cycling in soils, they involved in processes such as oxidation, nitrification, ammonification, nitrogen fixation, and other processes which lead to decomposition of soil organic matter and releasing essential inorganic plant nutrients to the soil. It has been reported that production of organic acids by PGPR participate in the conversion of insoluble form of phosphorus to soluble forms (Kurokura et al., 2017).

Egyptian J. Desert Res., 69, Special Issue, 59-75 (2019) 
Table (5). Effect of mineral fertilizer levels and biofertilizers on available minerals in the rhizosphere of barley plant during 2016-2017 seasons under salt conditions.

\begin{tabular}{|c|c|c|c|c|c|}
\hline \multirow[b]{2}{*}{$\begin{array}{l}\text { NPK } \\
\text { levels }\end{array}$} & \multirow[b]{2}{*}{ Inoculation } & \multicolumn{2}{|c|}{2016} & \multicolumn{2}{|c|}{2017} \\
\hline & & $\begin{array}{c}\text { Available } \\
\text { nitrogen } \\
\text { (mg/kg } \\
\text { soil) }\end{array}$ & $\begin{array}{c}\text { Available } \\
\text { phosphorus } \\
\text { (mg/kg } \\
\text { soil) }\end{array}$ & $\begin{array}{c}\text { Available } \\
\text { nitrogen } \\
\text { (mg/kg } \\
\text { soil) }\end{array}$ & $\begin{array}{c}\text { Available } \\
\text { phosphorus } \\
\text { (mg/kg } \\
\text { soil) }\end{array}$ \\
\hline \multirow{4}{*}{$\begin{array}{c}50 \% \\
(120 \\
\mathrm{kg} / \mathrm{ha})\end{array}$} & Control & $8.4^{\mathrm{i}}$ & $4.7^{\mathrm{f}}$ & $11.7^{\mathrm{j}}$ & $5.7^{\mathrm{h}}$ \\
\hline & PDB & $15.5^{\mathrm{f}}$ & $6.8^{\mathrm{de}}$ & $16.8^{\mathrm{i}}$ & $7.3^{\mathrm{g}}$ \\
\hline & Azot & $15.8^{\mathrm{f}}$ & $6.2^{\mathrm{e}}$ & $18.3^{\mathrm{h}}$ & $6.8^{\mathrm{g}}$ \\
\hline & Mixed & $16.5^{\mathrm{e}}$ & $7.5^{\mathrm{cd}}$ & $20.5^{\mathrm{g}}$ & $8.5^{\mathrm{f}}$ \\
\hline \multirow{4}{*}{$\begin{array}{c}75 \% \\
(180 \\
\mathrm{kg} / \mathrm{ha})\end{array}$} & Control & $13.0^{\mathrm{h}}$ & $6.1^{\mathrm{e}}$ & $17.9^{\mathrm{h}}$ & $7.0^{\mathrm{g}}$ \\
\hline & PDB & $17.4^{\mathrm{d}}$ & $8.0 b^{c}$ & $24.7^{\mathrm{e}}$ & $11.4^{\mathrm{bc}}$ \\
\hline & Azot & $19.4^{\mathrm{c}}$ & $7.5^{\mathrm{cd}}$ & $29.3^{\mathrm{c}}$ & $11.1^{\mathrm{cd}}$ \\
\hline & Mixed & $21.5^{\mathrm{a}}$ & $8.7^{\mathrm{ab}}$ & $33.5^{\mathrm{a}}$ & $12.2^{\mathrm{a}}$ \\
\hline \multirow{4}{*}{$\begin{array}{c}100 \\
\% \\
(240 \\
\mathrm{kg} / \mathrm{ha})\end{array}$} & Control & $13.9^{\mathrm{g}}$ & $6.3^{\mathrm{e}}$ & $18.0^{\mathrm{h}}$ & $7.4^{\mathrm{g}}$ \\
\hline & PDB & $17.3^{\mathrm{d}}$ & $7.7^{\mathrm{c}}$ & $23.2^{\mathrm{f}}$ & $10.2^{\mathrm{e}}$ \\
\hline & Azot & $19.4^{\mathrm{c}}$ & $7.4^{\mathrm{cd}}$ & $28.0^{\mathrm{d}}$ & $10.7^{\mathrm{de}}$ \\
\hline & Mixed & $20.9^{\mathrm{b}}$ & $8.7^{\mathrm{ab}}$ & $31.6^{\mathrm{b}}$ & $11.7^{\mathrm{ab}}$ \\
\hline \multicolumn{2}{|c|}{ LSD at 0.05} & 0.52 & 0.72 & 0.44 & 0.66 \\
\hline
\end{tabular}

5. Effect of Mineral Fertilizer Levels and Biofertilizers on Chemical Contents of Barley Plant During 2016 and 2017 Seasons Under Salt Conditions

Application of N2-fixing and P-solubilizing PGPR strains significantly promoted nitrogen and phosphorus contents in barely plants as well as protein contents (Table 6). The highest N, P and protein contents were obtained from mixed inoculation combined with $75 \%$ of NPK level, which increased $\mathrm{N}$ contents of plant by 134 and $156 \%$, P content by 60.1 and $94.6 \%$ and protein content by 135.2 and $156.1 \%$ compared with the control treatment in the two seasons, respectively. The previous studies have been reported similar findings on cowpea (Marwa et al., 2018), rice (Mohaseb et al., 2019), wheat (Attia and El Salam, 2016). El-Mekser et al. (2016) recorded a significant increase in nitrogen, phosphorus and potassium level in biofertilized treatments corn plants relative to control, they also observed a significant increase in water- and salt-soluble proteins (albumins and globulins) fractions percentage by biofertilization application. 
Table (6). Effect of mineral fertilizer levels and biofertilizers on chemical contents of barley plant during 2016 and 2017 seasons under salt conditions.

\begin{tabular}{|c|c|c|c|c|c|c|c|}
\hline \multirow[b]{2}{*}{ NPK levels } & \multirow[b]{2}{*}{ Inoculation } & \multicolumn{3}{|c|}{2016} & \multicolumn{3}{|c|}{2017} \\
\hline & & $\begin{array}{l}\text { Total N } \\
\text { content }\end{array}$ & $\begin{array}{l}\text { Total } P \\
\text { content }\end{array}$ & $\begin{array}{c}\text { Total } \\
\text { protien }\end{array}$ & $\begin{array}{l}\text { Total N } \\
\text { content }\end{array}$ & $\begin{array}{l}\text { Total } P \\
\text { content }\end{array}$ & $\begin{array}{c}\text { Total } \\
\text { protien }\end{array}$ \\
\hline \multirow{4}{*}{$\begin{array}{c}50 \% \\
(120 \mathrm{~kg} / \mathrm{ha})\end{array}$} & Control & $0.89^{\mathrm{g}}$ & $0.27^{\mathrm{i}}$ & $5.47^{\mathrm{g}}$ & $1.15^{\mathrm{f}}$ & $0.30^{\mathrm{f}}$ & $7.19^{f}$ \\
\hline & PDB & $1.33^{\mathrm{e}}$ & $0.34^{\mathrm{g}}$ & $8.33^{\mathrm{e}}$ & $1.61^{\mathrm{e}}$ & $0.40^{\mathrm{de}}$ & $10.06^{\mathrm{e}}$ \\
\hline & Azot & $1.91^{\mathrm{cd}}$ & $0.36^{\mathrm{f}}$ & $11.94^{\mathrm{cd}}$ & $2.33^{c}$ & $0.42^{\mathrm{d}}$ & $14.58^{c}$ \\
\hline & Mixed & $2.03^{\mathrm{bc}}$ & $0.42^{\mathrm{e}}$ & $12.68^{b c}$ & $2.56^{\mathrm{b}}$ & $0.46^{\mathrm{c}}$ & $16.00^{\mathrm{b}}$ \\
\hline \multirow{4}{*}{$\begin{array}{c}75 \% \\
(180 \mathrm{~kg} / \mathrm{ha})\end{array}$} & Control & $1.07^{\mathrm{f}}$ & $0.33^{\mathrm{h}}$ & $6.67^{\mathrm{f}}$ & $1.23^{\mathrm{f}}$ & $0.37^{\mathrm{e}}$ & $7.69^{f}$ \\
\hline & PDB & $1.79^{d}$ & $0.49^{c}$ & $11.21^{\mathrm{d}}$ & $1.96^{\mathrm{d}}$ & $0.58^{b}$ & $12.25^{\mathrm{d}}$ \\
\hline & Azot & $2.11^{\mathrm{b}}$ & $0.48^{\mathrm{cd}}$ & $13.19^{\mathrm{b}}$ & $2.67^{b}$ & $0.57^{b}$ & $16.69^{b}$ \\
\hline & Mixed & $2.51^{\mathrm{a}}$ & $0.53^{\mathrm{a}}$ & $15.69^{\mathrm{a}}$ & $3.15^{\mathrm{a}}$ & $0.72^{\mathrm{a}}$ & $19.69^{\mathrm{a}}$ \\
\hline \multirow{4}{*}{$\begin{array}{c}100 \% \\
(240 \mathrm{~kg} / \mathrm{ha})\end{array}$} & Control & $1.15^{\mathrm{f}}$ & $0.35 \mathrm{f}^{\mathrm{g}}$ & $7.21^{\mathrm{f}}$ & $1.28^{\mathrm{f}}$ & $0.38^{\mathrm{e}}$ & $7.98^{f}$ \\
\hline & PDB & $1.90^{\mathrm{cd}}$ & $0.48^{\mathrm{cd}}$ & $11.89^{\mathrm{cd}}$ & $2.10^{\mathrm{d}}$ & $0.56^{\mathrm{b}}$ & $13.13^{\mathrm{d}}$ \\
\hline & Azot & $2.04^{\mathrm{bc}}$ & $0.47^{\mathrm{d}}$ & $12.73^{b c}$ & $2.63^{b}$ & $0.55^{\mathrm{b}}$ & $16.46^{\mathrm{b}}$ \\
\hline & Mixed & $2.19^{b}$ & $0.51^{b}$ & $13.69^{\mathrm{b}}$ & $3.00^{\mathrm{a}}$ & $0.71^{\mathrm{a}}$ & $18.77^{\mathrm{a}}$ \\
\hline \multicolumn{2}{|c|}{ LSD at 0.05} & 0.08 & 0.01 & 1.03 & 0.19 & 0.03 & 1.19 \\
\hline
\end{tabular}

\section{Effect of Mineral Fertilizer Levels and Biofertilizers on Yield and its Components of Barley Plant During 2016 and 2017 Seasons Under Salt Conditions}

The results in table (7) reveal that the combination between PGPR inoculations and mineral fertilizer levels significantly enhanced yield and yield components of barley plants growing under saline conditions. Results showed that spikes $/ \mathrm{m}^{2}$ numbers (SN), 1000-grains weight $(\mathrm{GW})$ and grain yield (GY) of barley plant in each of the two seasons significantly increased by biofertilizers application compared with the control. The lowest SN, GW and GY were recorded in the control treatment whereas the highest SN (392 and 441), GW (41.33 and $46.67 \mathrm{~g}$ ) and GY (2.41 and 2.92 ton $\left.\mathrm{fed}^{-1}\right)$, were recorded from mixed PGPR inoculations combined with $75 \%$ of NPK fertilizer level in two years, respectively.

The increase in yield and its component in treatments received biofertilizer mainly attributed to the beneficial effect of biofertilizer application to the soil led to improved soil physical, biological and chemical properties and in turn resulted in more release of available nutrients to plant root (Boostani et al., 2014). Similar results were reported on rice, soybean, canola and barley plants where the inoculation with PGPR along with reduced level of chemical fertilizers mostly increased growth and yield of each crop 
(Hafeez, 2019; Egamberdieva et al., 2017 and Dadashzadeh et al., 2018). The application of biofertilizer with beneficial PGP properties improved leaf chlorophyll, plant nutrient uptake and grain protein content. Naher et al. (2016) revealed that the use of chemical fertilizer can be minimized by $50 \%$ and improve rice yield with the supplement of 5 ton ha ${ }^{-1}$ of bio-organic fertilizer.

Table (7). Effect of mineral fertilizer levels and biofertilizers on yield and its components of barley plant during 2016 and 2017 seasons under salt conditions.

\begin{tabular}{|c|c|c|c|c|c|c|c|}
\hline \multirow[b]{2}{*}{ NPK levels } & \multirow[b]{2}{*}{ Inoculation } & \multicolumn{3}{|c|}{2016} & \multicolumn{3}{|c|}{2017} \\
\hline & & $\begin{array}{l}\text { No. of } \\
\text { spikes } \mathbf{m}^{-2}\end{array}$ & $\begin{array}{l}\text { Weight } \\
\text { of 1000- } \\
\text { grains } \\
\text { (g) }\end{array}$ & $\begin{array}{r}\text { Grain yield } \\
\left(\text { ton fed } \text { fed }^{-1}\right)\end{array}$ & $\begin{array}{l}\text { No. of } \\
\text { spikes } \mathbf{m}^{-2}\end{array}$ & $\begin{array}{l}\text { Weight of } \\
\text { 1000- } \\
\text { grains } \\
\text { (g) }\end{array}$ & $\begin{array}{r}\text { Grain yield } \\
\left.\text { (ton fed }^{-1}\right)\end{array}$ \\
\hline \multirow{4}{*}{$\begin{array}{c}50 \% \\
(120 \mathrm{~kg} / \mathrm{ha})\end{array}$} & Control & $306.3^{\mathrm{k}}$ & $14.67^{\mathrm{h}}$ & $1.37^{\mathrm{k}}$ & $213.0^{\mathrm{i}}$ & $17.33^{\mathrm{i}}$ & $1.66^{\mathrm{j}}$ \\
\hline & PDB & $309.0^{j}$ & $22.00^{\mathrm{g}}$ & $2.06^{\mathrm{h}}$ & $265.3^{\mathrm{g}}$ & $20.33^{\mathrm{h}}$ & $2.34^{\mathrm{g}}$ \\
\hline & Azot & $322.3^{\mathrm{h}}$ & $26.33^{\mathrm{f}}$ & $2.10^{\mathrm{g}}$ & $302.7^{\mathrm{f}}$ & $21.33^{\mathrm{g}}$ & $2.43^{\mathrm{f}}$ \\
\hline & Mixed & $329.0^{\mathrm{g}}$ & $28.67^{\mathrm{e}}$ & $2.20^{\mathrm{d}}$ & $312.7^{\mathrm{f}}$ & $25.67^{\mathrm{f}}$ & $2.49^{\mathrm{e}}$ \\
\hline \multirow{4}{*}{$\begin{array}{c}75 \% \\
(180 \mathrm{~kg} / \mathrm{ha})\end{array}$} & Control & $328.0^{\mathrm{g}}$ & $21.33^{\mathrm{g}}$ & $1.61^{\mathrm{i}}$ & $247.3^{\mathrm{h}}$ & $25.67^{\mathrm{f}}$ & $1.87^{\mathrm{h}}$ \\
\hline & PDB & $352.3^{\mathrm{e}}$ & $32.67^{d}$ & $2.17^{\mathrm{e}}$ & $384.7^{\mathrm{de}}$ & $36.00^{\mathrm{d}}$ & $2.50^{\mathrm{e}}$ \\
\hline & Azot & $371.0^{\mathrm{c}}$ & $36.33^{\mathrm{bc}}$ & $2.26^{\mathrm{c}}$ & $401.7^{\mathrm{bc}}$ & $42.67^{b}$ & $2.79^{b}$ \\
\hline & Mixed & $392.0^{\mathrm{a}}$ & $41.33^{\mathrm{a}}$ & $2.41^{\mathrm{a}}$ & $441.0^{\mathrm{a}}$ & $46.67^{\mathrm{a}}$ & $2.92^{\mathrm{a}}$ \\
\hline \multirow{4}{*}{$\begin{array}{c}100 \% \\
(240 \mathrm{~kg} / \mathrm{ha})\end{array}$} & Control & $317.7^{\mathrm{i}}$ & $22.67^{\mathrm{g}}$ & $1.58^{\mathrm{j}}$ & $224.0^{\mathrm{i}}$ & $26.33^{\mathrm{f}}$ & $1.82^{\mathrm{i}}$ \\
\hline & PDB & $343.0^{\mathrm{f}}$ & $31.33^{\mathrm{d}}$ & $2.14^{\mathrm{f}}$ & $373.3^{\mathrm{e}}$ & $34.67^{e}$ & $2.43^{\mathrm{f}}$ \\
\hline & Azot & $362.3^{\mathrm{d}}$ & $35.33^{\mathrm{c}}$ & $2.21^{\mathrm{d}}$ & $390.3^{\mathrm{cd}}$ & $38.67^{\mathrm{c}}$ & $2.58^{\mathrm{d}}$ \\
\hline & Mixed & $378.0^{\mathrm{b}}$ & $37.33^{\mathrm{b}}$ & $2.34^{\mathrm{b}}$ & $410.0^{\mathrm{b}}$ & $43.00^{\mathrm{b}}$ & $2.74^{\mathrm{c}}$ \\
\hline \multicolumn{2}{|c|}{ LSD at 0.05} & 2.28 & 1.93 & 0.19 & 11.42 & 0.76 & 0.02 \\
\hline
\end{tabular}

\section{CONCLUSIONS}

Microbial inoculation of barley seeds with dual culture of $A$. chrococcum and B. subtilis, could reduce costly mineral fertilizers in barley production even in saline soils and provide plant nutrition requirement resulted in an increase in growth and productivity of barley plant. It could increase mineral concentration in the grain, thus reduced hidden hunger. It also improves soil biological structure and availability of nutrient. It can be concluded that bacteria used in this study may well be appropriate alone or in combination to achieve sustainable and ecological agricultural production in this region. 


\section{REFERENCES}

Abbas, R., S. Rasul, K. Aslam, M. Baber, M. Shahid, F. Mubeen and T. Naqqash (2019). Halotolerant PGPR: A hope for cultivation of saline soils. Journal of King Saud University-Science, 31: 1195-1201.

Allen, O.N. (1959). In: "Experiments in Soil Bacteriology". University of Wiscosin Second printing, $202 \mathrm{pp}$.

Attia, M.A. and A.A. El Salam (2016). Effect of mineral, organic and biofertilizer on yield and yield components of bread wheat at Siwa Oasis. Alexandria Journal of Agricultural Sciences, 61 (3): 211-219.

Ayman, M.H.A. (2015). Assessment of water quality of wastewaters of Bahr El-Baqar, Bilbies and El-Qalyubia drains in east delta, Egypt for irrigation purposes. Egypt J. Soil Sci., 55: 119-146.

Babu, S., A. Sheeba, P. Yogameenakshi, J. Anbumalarmathi and P. Rangasamy (2007). Effect of salt stress in the selection of salt tolerance hybrids in rice (Oryza sativa L.) under in vitro and in vivo condition. Asian J. Plant Sci., 69: 137-142.

Bartels, D. and R. Sunkar (2005). Drought and salt tolerance in plants. CritRev. Plant Sci., 24: 23-58.

Bender, M.R. and C.W. Wood (2000). Total Phosphorus in Soil. In: "Methods of Phosphorus Analysis for Soils, Sediments, Residuals, and Waters" Pierzynski, G.M. (Ed.). Southern Cooperative Series Bulletin No. 396, US Department of Agriculture and North Carolina State University, Raleigh, 2000, p. 45-49 (Southern Extension/Research ActivityInformation Exchange Group 17), 45.

Bergey, D.H., N.R. Krieg and J.G. Holt (1984). In: "Bergey's Manual of Systematic Bacteriology". Williams and Wilkins Publication Co., Michigan, USA.

Bhalodia, N.R., P.B. Nariya, R.N. Acharya and V.J. Shukla (2013). In vitro antioxidant activity of hydro alcoholic extract from the fruit pulp of Cassia fistula Linn. Ayu, 34 (2): 209.

Bhattacharyya, P.N. and D.K. Jha (2012). Plant growth-promoting rhizobacteria (PGPR): emergence in agriculture. World J. Microbiol. Biotechnol., 28: 1327-1350.

Boostani, H.M., M. Chorom, A. Moezi and N. Enayatizamir (2014). Mechanisms of plant growth promoting rhizobacteria (PGPR) and mycorrhizae fungi to enhancement of plant growth under salinity stress. Sci. J. Biol. Sci., 3 (11): 98-107.

Cappuccino, J.G. and N. Sherman (1992). Biochemical Activities of Microorganisms. In: "Microbiology, A Laboratory Manual". The Benjamin / Cummings Publishing Co., California, USA.

Cardelli, R., G. Vanni, L. Guidi, F. Marchini and A. Saviozzi (2014). Antioxidant capacity in urban soils. Landscape and Urban Planning, 124: 66-75.

Egyptian J. Desert Res., 69, Special Issue, 59-75 (2019) 
Casida, L.E., D.A. Klein and T. Santoro (1964). Soil dehydrogenase activity. Soil Sci., 98: 371-376.

Chen, L., C. Li, Q. Feng, Y. Wei, H. Zheng, Y. Zhao, Y. Feng and H. Li (2017). Shifts in soil microbial metabolic activities and community structures along a salinity gradient of irrigation water in a typical arid region of China. Science of the Total Environment, 598: 64-70.

Chowdhury, N., A.S. Nakatani, R. Setia and P. Marschner (2011). Microbial activity and community composition in saline and non-saline soils exposed to multiple drying and rewetting events. Plant and Soil, 348: 103-113.

Dadashzadeh, S., R.S. Sharifi and S. Farzaneh (2018). Physiological and biochemical responses of barley to application of bio-fertilizers and nano iron oxide under salinity stress in greenhouse. Bangladesh Journal of Botany, 47(4): 863-875.

Egamberdieva, D., S. Wirth, D. Jabborova, L.A. Räsänen and H. Liao (2017). Coordination between Bradyrhizobium and Pseudomonas alleviates salt stress in soybean through altering root system architecture. Journal of Plant Interactions, 12 (1): 100-107.

Eisa, S.S., A.M., Ibrahim, H.S. Khafaga and S.A Shehata (2012). Alleviation of adverse effects of salt stress on sugar beet by pre-sowing seed treatments. J. Appl. Sci. Res., 8 (2): 799-806.

El-Mekser, H.K.A., Z.E.O.M. Mohamed and W.M Elsayed (2016). Yellow corn Productivity and quality Under Using Different minerals and Biofertilizer rates. Corpus ID: 21284503

Emtiazi, G., Z. Ethemadifar and M.H. Habibi (2004). Production of extracellular polymer in Azotobacter and biosorption of metal by exopolymer. Afr. J. Biotechnol., 3: 330-333.

Etesami, H. and D.K. Maheshwari (2018). Use of plant growth promoting rhizobacteria (PGPRs) with multiple plant growth promoting traits in stress agriculture: action mechanisms and future prospects. Ecotoxicology and Environmental Safety, 156: 225-246.

Ghanbari, A., M. Babaeian, Y. Esmaeilian, A. Tavassoliand and A. Asgharzade (2012). The effect of cattle manure and chemical fertilizer on yield and yield component of barley (Hordeum vulgare). African Journal of Agricultural Research, 7 (3): 504-508.

Hafeez, M. (2019). Effect of halotolerant bio-fertilizer formulations on production of rice (Oryza sativa L.) in sodic soil of Eastern Plain Zone of Uttar Pradesh. Ph.D. Thesis, Department of Industrial Microbiology, Jacob Institute of Biotechnology and Bioengineering, Faculty of Engineering and Technology, Sam Higginbottom University of Agriculture, Technology and Sciences, Prayagraj (Allahabad), India.

Jofre', E., S. Fischer, V. Rivarola, H. Balegno and G. Mori (1998). Saline stress affects the attachment of Azospirillum brasilense $\mathrm{Cd}$ to maize and wheat roots. Can. J. Microbiol., 44: 416-422.

Egyptian J. Desert Res., 69, Special Issue, 59-75 (2019) 
Kulbat, K. (2016). The role of phenolic compounds in plant resistance. Biotechnol. Food Sci., 80 (2): 97-108.

Kurokura, T., S. Hiraide, Y. Shimamura and K. Yamane (2017). PGPR improves yield of strawberry species under less-fertilized conditions. Environmental Control in Biology, 55 (3): 121-128.

Magomya, A.M., D. Kubmarawa, J.A. Ndahi and G.G. Yebpella (2014). Determination of plant proteins via the kjeldahl method and amino acid analysis: a comparative study. International Journal of Scientific and Technology Research, 3 (4): 68-72.

Marwa, A.A., F.H. El-Agyzy and A.S. Khaled (2018). Influence of nitrogen sources and bio-fertilizer on soil nutrients, yield and quality of cowpea under saline soil conditions. Asian Soil Research Journal, 1 (4): 1-14.

Mohaseb, M.I., M.H. Kenawy and K.A. Shaban (2019). Role of mineral and bio-fertilizers on some soil properties and rice productivity under reclaimed saline soils. Asian Soil Research Journal, 2 (1): 1-12.

Naher, U.A., Q.A. Panhwar, R. Othman, M.R. Ismail and Z. Berahim (2016). Biofertilizer as a supplement of chemical fertilizer for yield maximization of rice. Journal of Agriculture Food and Development, 2 (0), 16-22.

Nguyen, L.T., Y. Osanai, K. Lai, I.C. Anderson, M.P. Bange, D.T. Tissue and B.K. Singh (2018). Responses of the soil microbial community to nitrogen fertilizer regimes and historical exposure to extreme weather events: Flooding or prolonged-drought. Soil Biology and Biochemistry, 118: 227-236.

Olutiola, P.O., O. Famurewa and H.G. Sonntag (2000). In: "Introduction to General Microbiology: A Practical Approach". $2^{\text {nd }}$ Edn., Bolabay Publications, Ikeja, Nigeria.

Page, A.L., R.H. Miller and D.R. Keeney. (1982). Methods of Soil Analysis, Part 2, Chemical and Microbiological Properties, 2nd ed., Agronomy Series No 9, American Society of Agronomy, Madison, WI.

Parlakova Karagöz, F. and A. Dursun (2019). A study of different bacterial formulations in increasing the nutrient content of bulb and leaf of Tulips and grown soil samples. Journal of Horticultural Science and Ornamental Plants, 11 (1): 52-65.

Patten, C.L. and B.R. Glick (2002). Role of Pseudomonas putida indoleacetic acid in development of the host plant root system. Appl. Environ. Microbiol., 68: 3795-3801.

Peach, K. and M.V. Tracy (1955). In: "Modern Methods of Plant Analysis". Vol III and IV, Springer Heidelberg, Berlin, p. 258-261.

Pikovskaya, R.I. (1948). Mobilization of phosphorous in soil in connection with vital activity of some microbial species. Microbiologiya, 17: 36270 .

Egyptian J. Desert Res., 69, Special Issue, 59-75 (2019) 
Rachid, D. and A. Bensoltane (2005). Effect of iron and growth inhibitors on siderophores production by Pseudomonas fluorescens. Afr. J. Biotechnol., 4: 697-702.

Reddy, M.S., R.I. Ilao and P.S. Faylon (2014). In: "Recent Advances in Biofertilizers and Biofungicides (PGPR) for Sustainable Agriculture". Cambridge Scholars Publishing.

Rimmer, D.L. (2006). Free radicals, antioxidants, and soil organic matter recalcitrance. European Journal of Soil Science, 57: 91-94.

Rimmer, D.L. and G.D. Abbott (2011). Phenolic compounds in $\mathrm{NaOH}$ extracts of UK soils and their contribution to antioxidant capacity. European Journal of Soil Sciences, 62: 285-294.

Shahid, M., M.S. Akram, M.A. Khan, M. Zubair, S.M. Shah, M. Ismail, G. Shabir, S. Basheer, K. Aslam and M. Tariq (2018). A phytobeneficial strain Planomicrobium sp. MSSA-10 triggered oxidative stress responsive mechanisms and regulated the growth of pea plants under induced saline environment. J. Appl. Microbiol., 124: 1566-1579.

Singh, K. (2016). Microbial and enzyme activities of saline and sodic soils. Land Degradation and Development, 27 (3): 706-718.

Skwaryło-Bednarz, B. and A. Krzepiłko (2007). Biological and antioxidant properties of soils from the protected zone of Roztocze National Park. Polish Journal of Environmental Studies, 16: 251-254.

SPSS (2014). SPSS base 21.1 for windows user's guide. SPSS Inc., Chicago IL.

Subba Rao, N.S. (1984). In: "Biofertilizers in Agriculture". Oxford and IBH Publishing Co., New Delhi.

Tahir, M. and M. Shehzadi (2017). Response of spring and autumn sunflower to chemical and bio-fertilizers for yield and quality traits. Pakistan Journal of Agricultural Research, 30 (2): 122-128.

Wang, Z., M. Gao, J. Wei, K. Ma, J. Pei, J. Zhang, Y. Zhou, Y. Yang and S. $\mathrm{Yu}$ (2016). Long-term effects of salinity on extracellular polymeric substances, microbial activity and microbial community from biofilm and suspended sludge in an anoxic-aerobic sequencing batch biofilm reactor. Journal of the Taiwan Institute of Chemical Engineers, 68: 275280.

Yaseen, R. and T. Yossif (2019). Functional microbial diversity in relation to soil characteristics and land uses of wadi Um Ashtan basin, NorthWestern Coast, Egypt. Egyptian Journal of Soil Science, 59 (3): 287297.

Yaseen, R.Y., S.M.A. El-Aziz, D.T. Eissa and A.M. Abou-Shady (2018). Application of biosurfactant producing microorganisms to remediate heavy metal pollution in El-Gabal El-Asfar area. Alex. Sci. Exch. J., 39: 17-34.

Yasin, N.A., W. Akram, W.U. Khan, S.R. Ahmad, A. Ahmad and A. Ali (2018). Halotolerant plant-growth promoting rhizobacteria modulate

Egyptian J. Desert Res., 69, Special Issue, 59-75 (2019) 
gene expression and osmolyte production to improve salinity tolerance and growth in Capsicum annum L. Environmental Science and Pollution Research, 25 (23): 23236-23250.

Zafar-ul-Hye, M., H.M. Farooq and M. Hussain (2015). Bacteria in combination with fertilizers promote root and shoot growth of maize in saline-sodic soil. Brazilian Journal of Microbiology, 46 (1): 97-102.

Egyptian J. Desert Res., 69, Special Issue, 59-75 (2019) 


\section{استجابة الشعير المزروع في التربة المتأثرة بالملوحة للأسمدة الحيوية و والمعدنية}

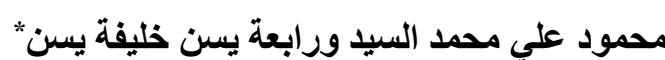

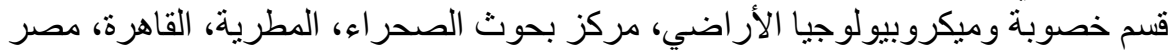

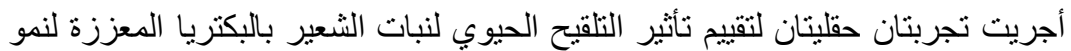

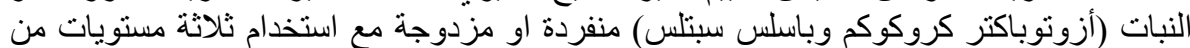

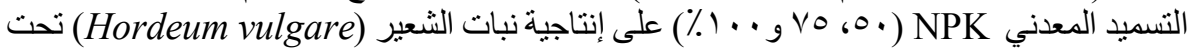

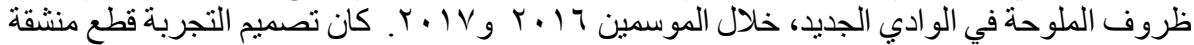

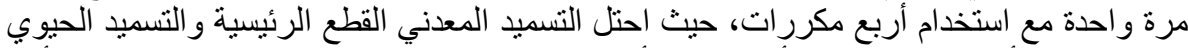

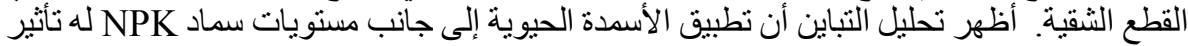

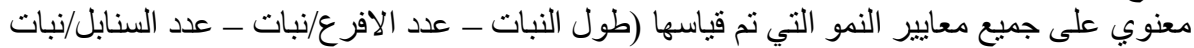

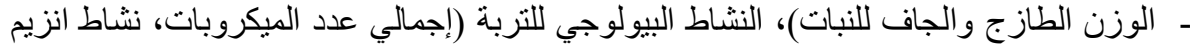

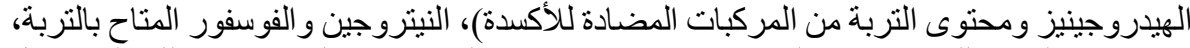

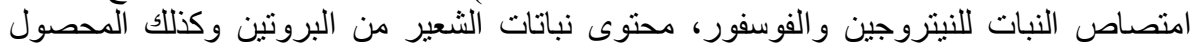

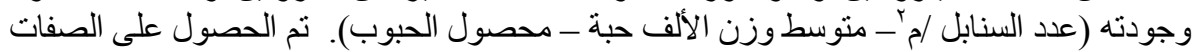

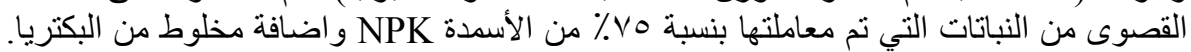

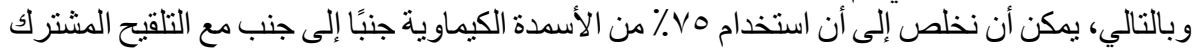

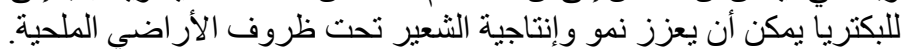

